\title{
Allelopathic Activity of Clover Species on Hairy Beggarticks's Seeds
}

\author{
Douglas Junior Bertoncelli1 ${ }^{*}$, Sérgio Miguel Mazaro², Pedro Valério Dutra de Moraes², \\ Jean Carlo Possenti², Adriano Lewandowski ${ }^{3}$, Nean Locatelli Dalacosta ${ }^{3}$, \\ Guilherme Augusto Cito Alves1, Gustavo Henrique Freiria1, Felipe Favoretto Furlan1 \\ ${ }^{1}$ Doutorando em agronomia pelo programa de pós-graduação em agronomia, da Universidade Estadual de \\ Londrina, Paraná, Brasil \\ ${ }^{2}$ Professor do curso de agronomia da Universidade Tecnológica Federal do Paraná, Campus Dois Vizinhos, \\ Paraná, Brasil \\ ${ }^{3}$ Aluno do curso de agronomia da Universidade Tecnológica Federal do Paraná, Campus Dois Vizinhos, Paraná, Brasil \\ Email: *dj_bertoncelli@hotmail.com
}

Received 18 May 2016; accepted 30 June 2016; published 4 July 2016

Copyright (C) 2016 by authors and OALib.

This work is licensed under the Creative Commons Attribution International License (CC BY). http://creativecommons.org/licenses/by/4.0/

(c) (i) Open Access

\section{Abstract}

The objective was to evaluate the allelopathic potential of clover in different extracts concentrations and obtained in different ways from hairy beggarticks's seeds germination and plantlets initial development. It was evaluated in $3 \times 3 \times 5$ factorial scheme, where, extracts obtained by infusion, maceration, and alcoholic from white clover, red clover, and arrowleaf clover, in four concentrations (2.5\%; $5.0 \% ; 7.5 \%$ and $10 \%$ ) and witness (distilled water), respectively. There were sown 100 seeds in germitest paper roll, in four repetitions, which were moisten with different extracts and/or distilled water, in accordance with treatment. The germination test was installed in growth chamber (BOD) with photo light/dark period of $12 / 12 \mathrm{~h}$ and temperature of $25^{\circ} \mathrm{C} \pm 1^{\circ} \mathrm{C}$. Germination evaluation was carried out daily and at the end of the experiment (10 days); the germination speed index (GSI), root length (RL) and aerial part (APL) were measured. It was carried out also infrared spectrum of extracts. It was observed that all extracts present effect on hairy beggarticks's seeds, causing reduction in germination, GSI, RL, and PCA. It was observed the presence of phenolic compounds in all extracts.

\section{Keywords}

Bidens sp., Isoflavonoids, Secondary Metabolites, Trifolium sp.

Subject Areas: Plant Science

\footnotetext{
${ }^{*}$ Corresponding author.
}

How to cite this paper: Bertoncelli, D.J., Mazaro, S.M., de Moraes, P.V.D., Possenti, J.C., Lewandowski, A., Dalacosta, N.L., Alves, G.A.C., Freiria, G.H. and Furlan, F.F. (2016) Allelopathic Activity of Clover Species on Hairy Beggarticks's Seeds. Open Access Library Journal, 3: e2749. http://dx.doi.org/10.4236/oalib.1102749 


\section{Introduction}

The genus Bidens sp., commonly known as hairy beggarticks, presents large incidence in South America, while in Brazil it is present in almost all of its territory [1]. This weed, for these authors, can be found all year long in crops, standing out for their aggressiveness, since in addition to setting competition with crops, it may be host for diseases and pests, causing huge losses in agriculture production.

The control of hairy beggarticks's and other weeds, with the use of coverage species with allelopathic potential has become a feasible alternative for agriculture systems, thus comprising crop rotation system [2]. The allelopathic effect may occur both during crop cycle and in subsequent crops [3].

Crops rotation exerts great influence in pests, diseases and weeds control in crops through allelopathy. Allelopathy may write off the need of used pesticides application, in addition to minimizing the environmental impacts derived from agricultural practices [4].

In its turn, allelopathy basic principle is set as any direct or indirect effect, either harmful or beneficial, of a plant or micro-organism over another, caused by the release of chemical compounds into the environment, known as allelochemicals [5].

Mazzafera [6] highlights that allelopathic compounds, in their majority, originate from the secondary metabolism of plants phenolic compounds. According to Taiz and Zeiger [7], clover plants present, among other substances, the class of compounds from the group of flavonoids, which present expressive biological activity and allelopathic action.

Moraes [8] highlight, in study with weeds, the use of arrowleaf clover (Trifolium vesiculosum) as source of allelopathic compounds as they observed that arrowleaf clover aqueous extract caused change in the hairy beggarticks's initial development and reduction of germination in seeds.

The work objective was to evaluate the allelopathic potential of clovers in different extract concentrations obtained under different ways about hairy beggarticks's seeds germination and initial development of plantlets.

\section{Material and Methods}

In extracts preparation, species of white clover (Trifolium repens L.), red clover (Trifolium pratensis L.), and arrowleaf clover (Trifolium vesiculosum) were used, which were farmed in field conditions. The used sowing density was $5 \mathrm{~kg} \cdot \mathrm{ha}^{-1}$ of seeds. Before sowing, mechanical control of weeds was undertaken and, then, sowing was carried out by throwing, followed by incorporation of seeds into the ground in average depth of $3 \mathrm{~cm}$. There was not any fertilization, irrigation, and pesticides application during the crop cycle. After 70 days from sowing, during the vegetative stage, collection of the clover plants aerial parts was done for extracts preparation.

The fresh collected material was dehydrated in forced air circulation oven, at $40^{\circ} \mathrm{C}$, thus avoiding possible loss of volatile allelopathic compounds. The material, after dehydration, was crushed in blade mill in order to decrease the size of particles and to increase the contact area of vegetal material and the solvent. To that end, it was used a stainless steel screen with mesh of 20, which is equivalent of particle size of $0.840 \mathrm{~mm}$.

The extracts were prepared in the concentration of $10 \% \mathrm{w} / \mathrm{v}$, based on dry matter content. The methods for extraction used were maceration, infusion, and alcoholic.

Maceration consists on the contact of vegetal material with water, at room temperature for preset period. In order to get the extract by maceration, it was used $50 \mathrm{~g}$ of clover powder that was mixed to $450 \mathrm{~mL}$ of cold, distilled water. It was set to rest after manual agitation in absence of light during 24 hours. Later, filtering was done with 3 micron filter paper, thus separating the solid part of the solution.

Infusion consists in throwing in boiling water over the vegetal material and, next, the recipient is covered with a lid for a preset period. It was used, for the extract obtained by this way, $450 \mathrm{~mL}$ of distilled water which was previously heated at $100^{\circ} \mathrm{C}$, adding next $50 \mathrm{~g}$ of clover powder, letting it rest for 20 minutes inside a closed recipient. In the sequence, filtering was done with 3 micron filter paper.

The alcoholic extract constitutes in a maceration process, but using alcohol as solvent. For this extract, it was used $50 \mathrm{~g}$ of clover powder immersed in $450 \mathrm{~mL}$ of ethylic alcohol at $92.8 \%$, kept resting for 24 hours at $25^{\circ} \mathrm{C}$ and without light. Filtering in filter paper (porosity of 3 microns), measuring the total volume of the solution after filtering. In sequence, the ethanol in the solution was removed by means of rotation evaporator. Ethanol was dissolved in distilled water until completing the initial volume of the solution obtained after filtering.

After preparation of extracts (10\%), they were diluted with distilled water until achieving the other concentrations of $2.5 \%$; $5 \%$ and $7.5 \%$. 
Hairy beggarticks's seeds from volunteer plants of the region were used. Seeds germination was undertaken in germitest paper roll over two sheets of paper that were moisten with extracts or distilled water, in accordance with the treatment. The amount of solution used was determined by multiplying twofold and half of paper weight. In each roll it were placed 100 hairy beggarticks's seeds. The germination test was installed in growth chamber (BOD) with light/dark photo period of $12 / 12 \mathrm{~h}$ at $25^{\circ} \mathrm{C} \pm 1^{\circ} \mathrm{C}$.

The experimental outlining was totally casualized, with four repetitions. Treatments were arranged in factorial scheme ( $3 \times 3 \times 4+$ witness), comprising of: A factor-clover species (white clover, red clover, and arrowleaf clover); B factor - extracts ways (maceration, infusion, and alcoholic); C factor-concentrations ( $0 \%, 2.5 \%$; $5 \%$; $7.5 \%$ and $10 \%$ weight/volume) of vegetal extracts or water. The counting of germinated seeds was done daily for 10 days in order to establish the germination speed index (GSI), obtained through the formula described by Maguire (1962) and modified by Wardle [9]:

$$
G S=N 1 / 1+N 2 / 2+N 3 / 3+\ldots . . N n / n,
$$

where, $N 1, N 2, N 3$, and $N n$ are the number of germinated seeds, and 1, 2, 3, and $\mathrm{n}$ are the number days after sowing. Those presenting emergence of aerial part and rootlet were considered as germinated seeds.

At the end of the period (10 days), germination, rootlet length (RL), and aerial part length (APL) were evaluated.

The results were tabulated and submitted to variance analysis by $\mathrm{F}$ test and, when there was statistics significance, comparison between averages was carried out, for clover species and type of extracts factors, using the Tukey test $(p \leq 0.05)$ and for the extracts concentration factor, regression analysis was undertaken. ASSISTAT program was used to carry out the statistics analyses.

In order to support the obtained results, an evaluation of compounds found in vegetal extracts through infra-red spectroscopy was carried out, and one sample of the vegetal extracts (the same used in the tests with seeds) was collected and freeze-dried to withdraw water from the sample. From powder gotten after freeze-dry, it was used $1 \mathrm{mg}$ of the sample from extracts and it was added $100 \mathrm{mg}$ of $\mathrm{KBr}$ (potassium bromide), which were macerated and later pressed to form a tablet. The tablet was inserted in the infra-red spectrometer and readings were made. The used spectra ranged from 250 to $4000 \mathrm{~cm}^{-1}$.

\section{Result and Discussion}

For the germination, RL, and APL variables there was interaction between the clover species, extraction way, and applied extract concentration factors.

According to data from Table 1, it is possible to observe that hairy beggarticks's seeds germination was most affected by the red clover extract with average reduction of $72.6 \%$. The red clover, with the alcoholic extraction, presented average reduction of about $78.7 \%$ in seeds germination.

Among the extraction ways that caused most reduction in hairy beggarticks's seeds germination was the alcoholic extract, regardless of clover species, with average reduction of about $76.5 \%$ when compared to witness.

Increased concentration of extracts, regardless of extraction way, resulted in reduction of hairy beggarticks's seeds germination, as seen in Figure 1.

Table 1. Hairy beggarticks's (Bidens sp.) seeds germination (\%) submitted to application of different extracts from clover species. UTFPR-Dois Vizinhos, 2014.

\begin{tabular}{ccccc}
\hline \multirow{2}{*}{ Type of extraction } & \multicolumn{3}{c}{ Clover species } \\
\cline { 2 - 5 } & White & Red & Arrowleaf & Mean \\
\hline Witness & $66 \pm 9.59^{\mathrm{aA}}$ & $66 \pm 9.59^{\mathrm{aA}}$ & $66 \pm 9.59^{\mathrm{aA}}$ & 62 \\
Infusion & $25 \pm 9.42^{\mathrm{aA}}$ & $18 \pm 9.40^{\mathrm{aB}}$ & $21 \pm 9.38^{\mathrm{aA}}$ & 21 \\
Maceration & $23 \pm 9.44^{\mathrm{aA}}$ & $23 \pm 9.37^{\mathrm{aB}}$ & $25 \pm 9.40^{\mathrm{aA}}$ & 24 \\
Alcoholic & $17 \pm 9.52^{\mathrm{bA}}$ & $13 \pm 9.39^{\mathrm{bB}}$ & $17 \pm 9.22^{\mathrm{bA}}$ & 15 \\
Mean & 32 & 29 & 31 & \\
\hline
\end{tabular}

Averages followed by the same lowercase letters in columns and by uppercase letter in the row do not differ in Tukey test ( $p$ $\leq 0.05)$. 


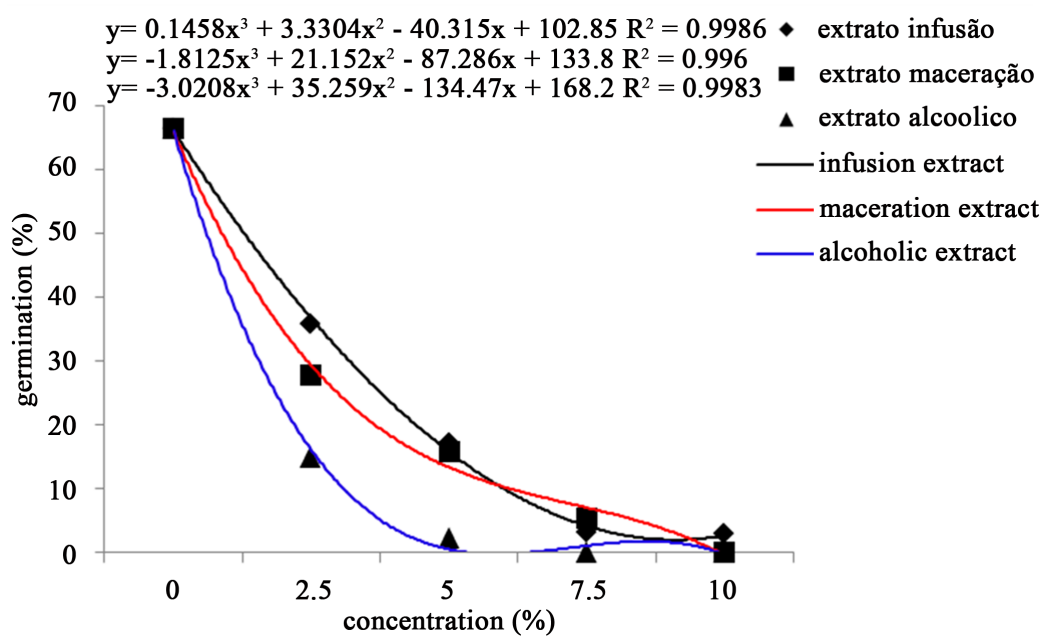

(a)

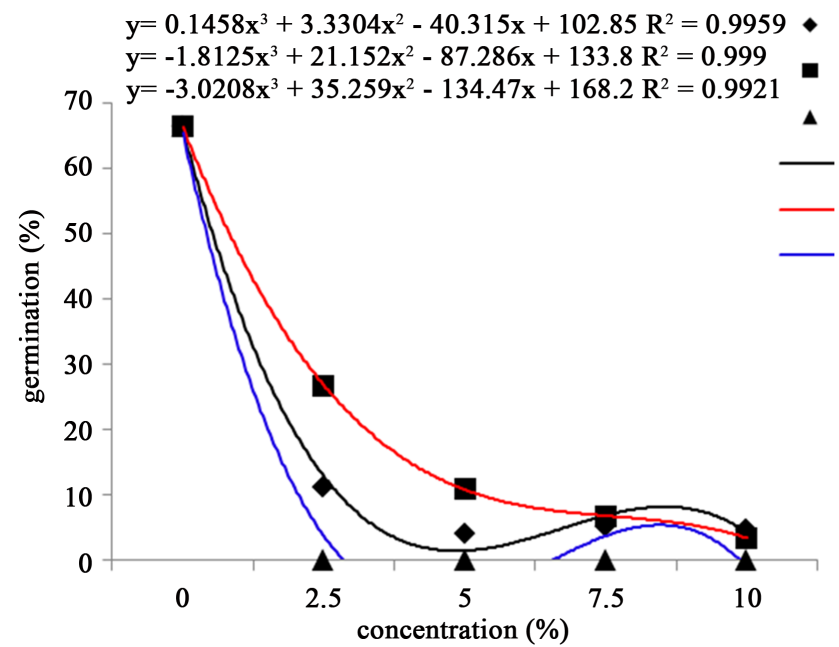

(b)

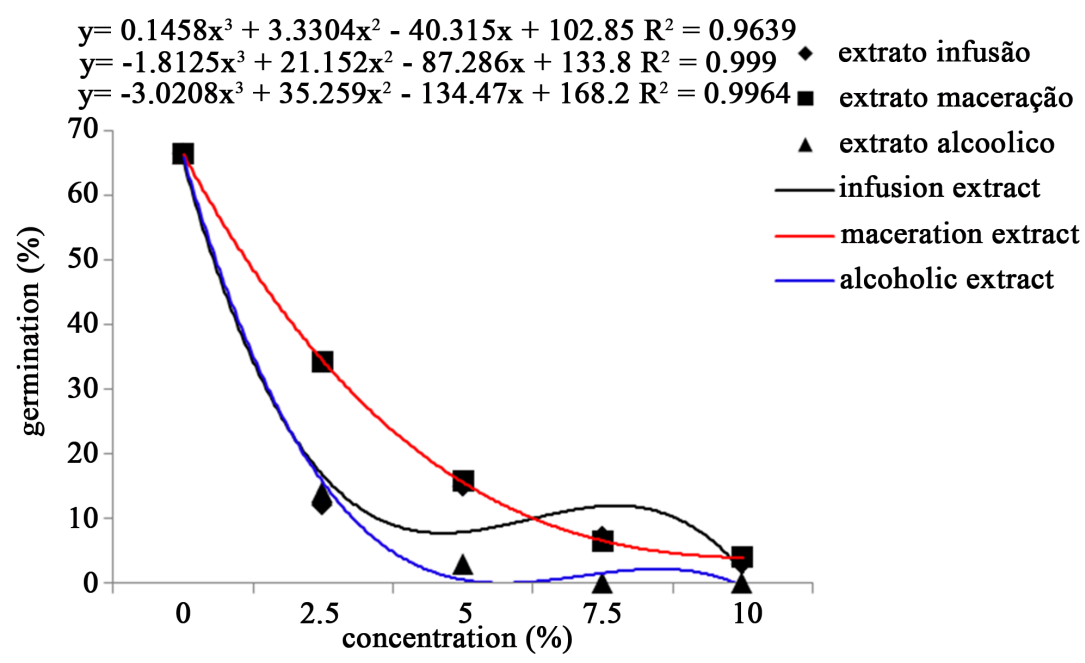

(c)

Figure 1. Hairy beggarticks's (Bidens sp.) seeds germination (\%) submitted to application of different extracts from clover species ((a)—white clover; (b)—red clover; (c)—arrowleaf clover), Dois Vizinhos, 2014. 
The red clover alcoholic extract inhibited hairy beggarticks's seeds germination from concentration of $2.5 \%$. In the other hand, this result was only seen in red clover and arrowleaf clover alcoholic extract from concentration of 5\%. Similar result was observed by Corsato [2], who noticed that application of sunflower leaves aqueous extract in low concentrations may fully inhibit hairy beggarticks's seeds germination.

Those results show that extraction by ethanol was more effective in removing compounds with allelopathic potential from clover plants, as those extracts presented greater effect on inhibiting hairy beggarticks's seeds germination.

The difference in hairy beggarticks's seeds germination among extraction methods confirms presumptions by Cruz [10], who mentioned that preparation way, application method, and products concentration are decisive factors in getting the results, since vegetal active principles are unstable and are not homogenously distributed in plants.

There was not interaction among those three factors for the germination speed variable (GSI), but there was interaction between extraction way and clover species, as it can be observed in Table 2.

Red clover presented most expressive results among the clover species in reducing GSI (Table 2), with reduction around 74\%. In the other hand, for the extraction way, alcoholic extraction presented the best result with reduction of around $76.9 \%$ of GSI when compared to witness.

The increased concentration in clover extracts resulted in delay of hairy beggarticks's seeds germination, as it can be seen in Figure 2.

Similar results were found by Fortes [11], when working with elderberry (Sambucus nigra L.) and lemongrass (Cymbopogon citratus) extracts they observed that increase in extracts concentration decreased hairy beggarticks's seeds GSI, reaching zero from $40 \%$ concentration of elderberry extract.

The results gotten in this work oppose Ferreira's statement [12], who stated that usually the final germination percentage is less influenced by presence of allelopathic compound in low concentrations, while the average germination speed is more sensitive, resulting in changes in the germination curve. It was observed in that experiment that both germination and GSI presented expressive reduction in values with application of clover extracts, even in low concentrations.

GSI and germination delay are favorable points in reducing weed population in crops, and clovers are a major tool in the integrated management of weed control, while it may be used in crops rotation during winter as, in addition to control weed, it still presents the feature of fixing nitrogen in the soil, thus benefiting the development of subsequent crop.

Regarding root length (RL), the extraction way that resulted in greater RL reductions was the alcoholic extract (Table 3), with average reduction of $61.1 \%$. Red clover extracts caused the greatest reductions in RL (average reduction of $42 \%$ ), except for the extract from maceration where the white clover presented lower RL values, with average reduction of $49.3 \%$ compared to witness.

The concentration increase of extracts used in hairy beggarticks's seeds germination reduced the growth of plantlets root system (Figure 3), showing the allelopathic potential of clover plants in decreasing the initial development of hairy beggarticks's plantlets, while that effect often considered as of major importance in allelopathy, as from the ecological standpoint, it is a more efficient selection mechanism than avoiding weed germination, because descendants are eliminated [13].

Table 2. Germination Speed Index (GSI) of hairy beggarticks's (Bidens sp.) seeds submitted to application of different extracts from clover species. UTFPR-Dois Vizinhos, 2014.

\begin{tabular}{|c|c|c|c|c|}
\hline \multirow{2}{*}{ Type of extraction } & \multicolumn{4}{|c|}{ Clover species } \\
\hline & White & Red & Arrowleaf & Mean \\
\hline Witness & $8.90 \pm 0.80^{\mathrm{aA}}$ & $8.90 \pm 0.80^{\mathrm{aA}}$ & $8.90 \pm 0.80^{\mathrm{aA}}$ & 8.90 \\
\hline Infusion & $3.11 \pm 0.85^{\mathrm{aA}}$ & $2.40 \pm 0.78^{\mathrm{aB}}$ & $2.82 \pm 0.66^{\mathrm{aA}}$ & 2.78 \\
\hline Maceration & $3.39 \pm 0.77^{\mathrm{aA}}$ & $2.75 \pm 0.65^{\mathrm{aB}}$ & $3.25 \pm 0.79^{\mathrm{aA}}$ & 3.13 \\
\hline Alcoholic & $2.26 \pm 0.81^{\mathrm{bA}}$ & $1.78 \pm 0.81^{\mathrm{bB}}$ & $2.12 \pm 0.64^{\mathrm{bA}}$ & 2.05 \\
\hline Mean & 4.41 & 3.96 & 4.27 & \\
\hline
\end{tabular}

Averages followed by the same lowercase letters in columns and by uppercase letter in the row do not differ in Tukey test ( $p$ $\leq 0.05)$. 


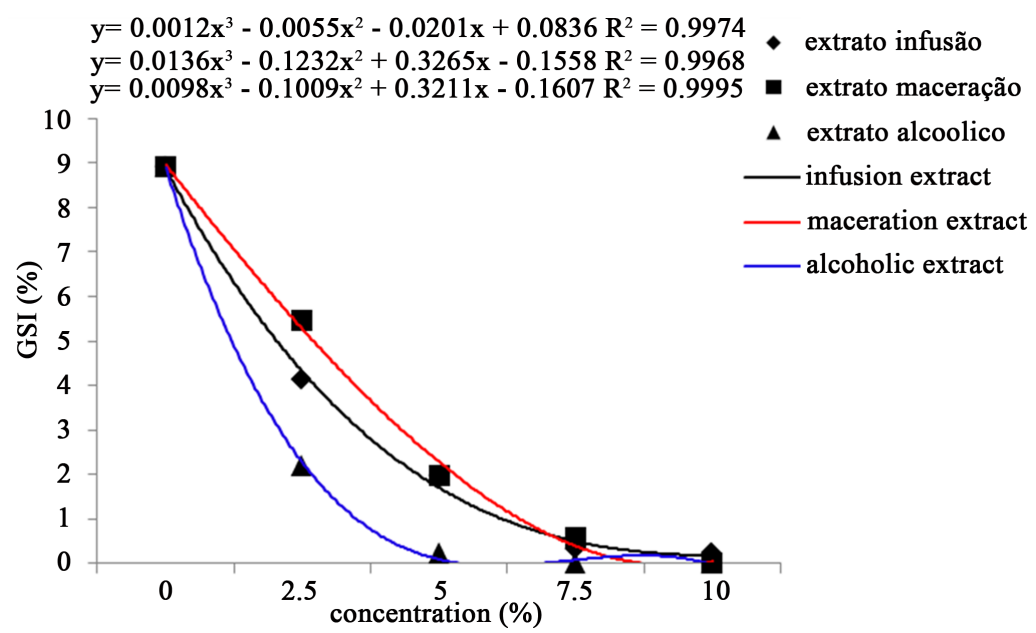

(a)

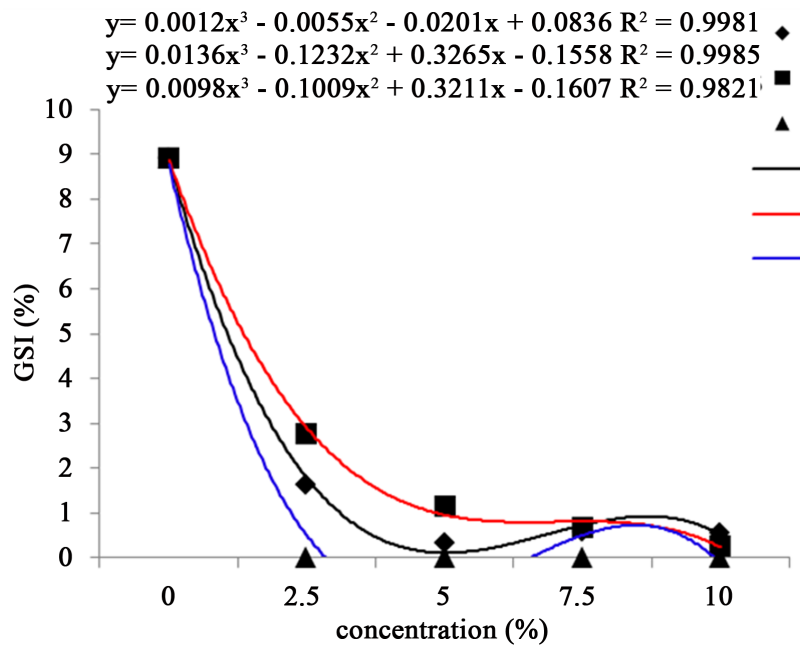

(b)

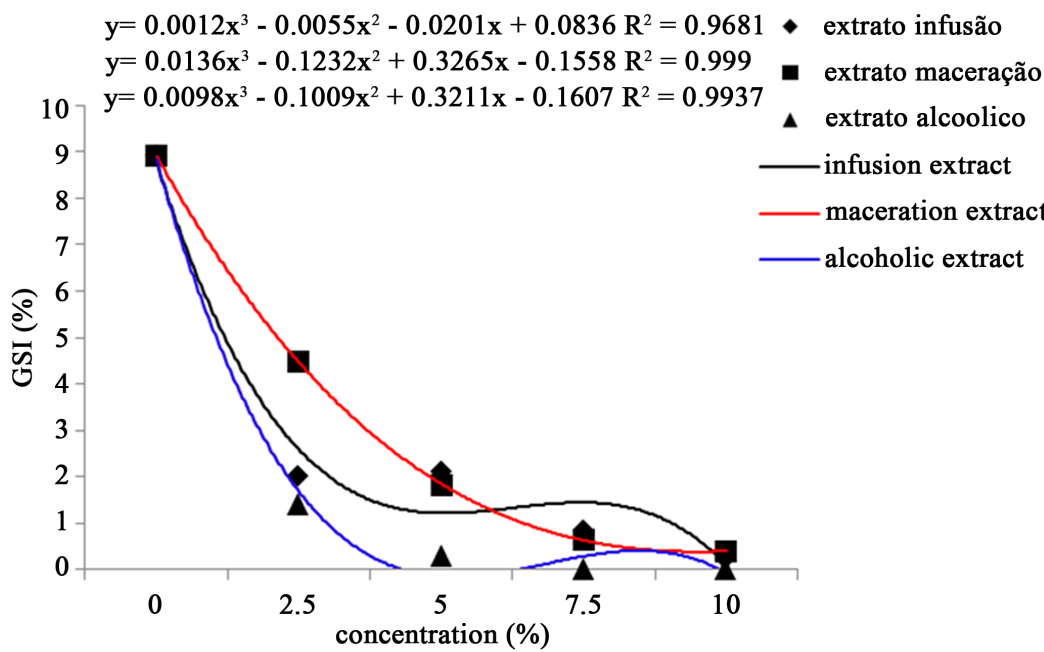

(c)

Figure 2. Germination Speed Index (IVG) of hairy beggarticks's (Bidens sp.) seeds submitted to application of different extracts of clover species ((a)—white clover; (b)—red clover; (c)—arrowleaf clover), UTFPR-Dois Vizinhos, 2014. 


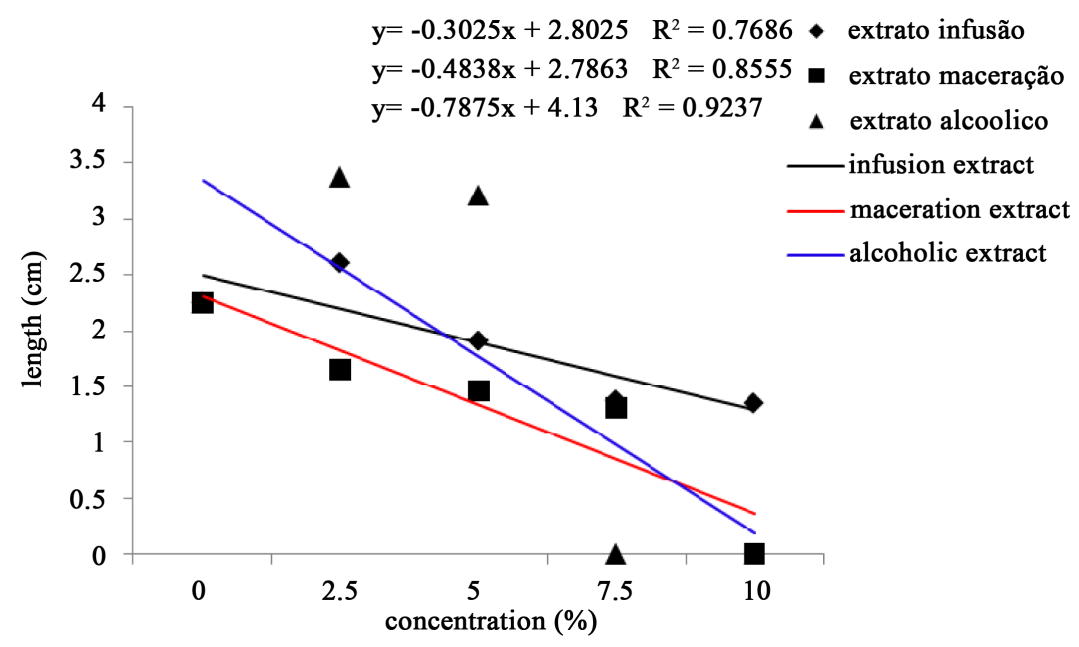

(a)

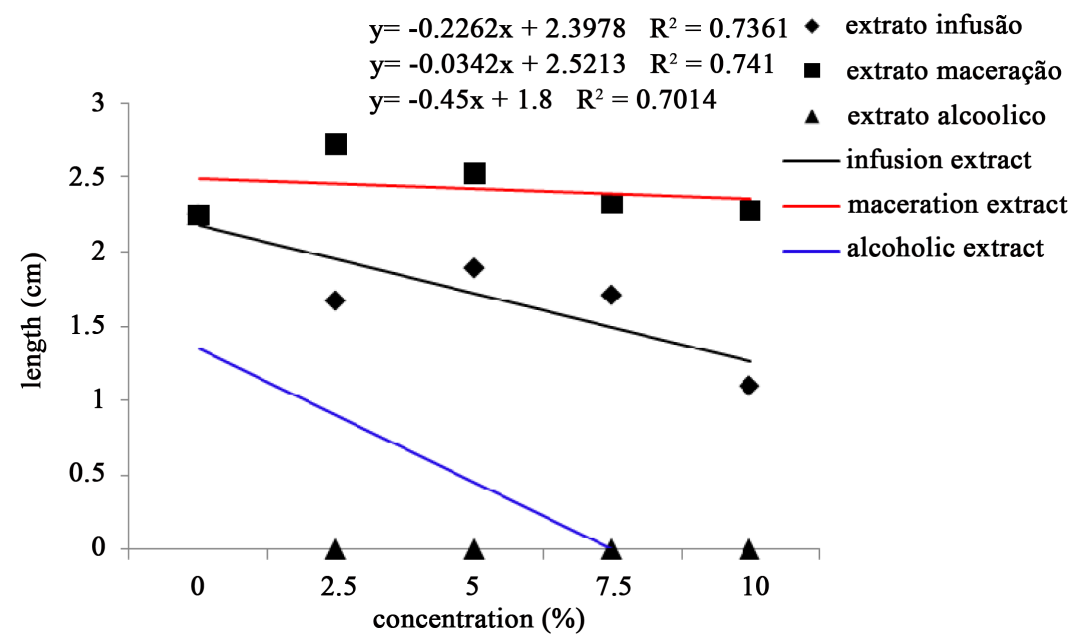

(b)

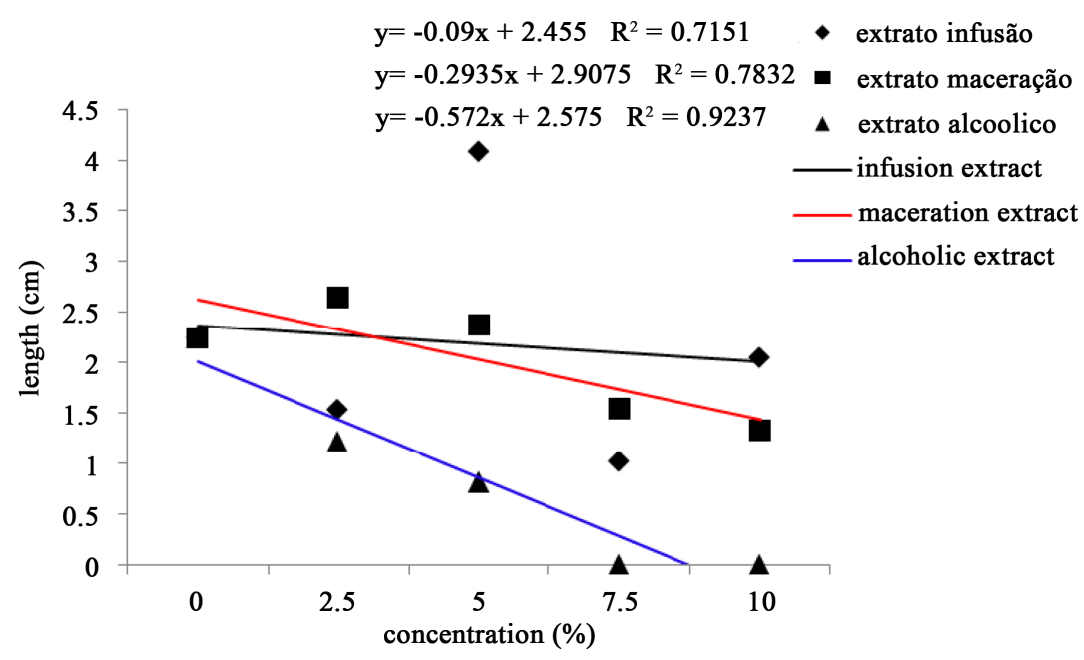

(c)

Figure 3. Root length (cm) of hairy beggarticks's (Bidens sp.) plantlets submitted to application of different extracts from clover species ((a)—-white clover; (b)—red clover; (c)—arrowleaf clover), UTFPR-Dois Vizinhos, 2014. 
Table 3. Root length (cm) of hairy beggarticks's plantlets (Bidens sp.) submitted to application of different extracts from clover species. UTFPR-Dois Vizinhos, 2014.

\begin{tabular}{ccccc}
\hline \multirow{2}{*}{ Type of extraction } & \multicolumn{3}{c}{ Clover species } \\
\cline { 2 - 4 } & White & Red & Arrowleaf & Mean \\
\hline Witness & $2.25 \pm 0.57^{\mathrm{aA}}$ & $2.25 \pm 0.57^{\mathrm{aA}}$ & $2.25 \pm 0.57^{\mathrm{aA}}$ & 2.25 \\
Infusion & $1.89 \pm 0.25^{\mathrm{aAB}}$ & $1.71 \pm 0.23^{\mathrm{bB}}$ & $2.15 \pm 0.26^{\mathrm{aA}}$ & 1.93 \\
Maceration & $1.33 \pm 0.17^{\mathrm{bB}}$ & $2.41 \pm 0.25^{\mathrm{aA}}$ & $2.02 \pm 0.20^{\mathrm{aA}}$ & 1.92 \\
Alcoholic & $1.76 \pm 0.20^{\mathrm{abA}}$ & $0.45 \pm 0.12^{\mathrm{cB}}$ & $0.85 \pm 0.14^{\mathrm{bB}}$ & 1.02 \\
Mean & 1.81 & 1.70 & 1.82 & \\
\hline
\end{tabular}

Averages followed by the same lowercase letters in columns and by uppercase letter in the row do not differ in Tukey test ( $p$ $\leq 0.05)$

Fortes [11], working with elderberry (Sambucus nigra L.) and lemongrass (Cymbopogon citratus) aqueous extracts reduced the root length of hairy beggarticks's plantlets.

Analyzing Neem's (Azadirachta indica) aqueous extract on hairy beggarticks's seeds, Rickli [14] observed that increase in concentration decreased seeds germination and GSI, reducing RL of plantlets as well as.

Similarly to RL, the aerial part length (APL) was more negatively affected by the red clover alcoholic extract (Table 4), followed by arrowleaf clover and white clover alcoholic extracts, with reductions of $80 \%, 48.1 \%$, and $42.1 \%$ respectively. The extracts gotten from alcohol were more efficient in reducing aerial part growth of hairy beggarticks's plantlets than extracts using water as solvent. In the other hand, red clover presented the most satisfactory results among clover species, with average PCA reduction of about $30.53 \%$ and $20.96 \%$ respectively.

White clover and arrowleaf clover extracts gotten through the maceration process presented increase of PCA with increased concentrations (Figure 4), but there was reduction of aerial part growth with increased concentrations from the $5 \%$ concentration, while the same fact was observed red clover extract by infusion. However, variations in length were not so expressive, in the other hand, increased concentrations reduced PCA for the other extracts.

Similar result was found by Hoffmann [15], where increased concentrations of oleander (Nerium oleander) and dumb cane (Dieffenbachia amoena) aqueous extracts decreased RL and PCA of hairy beggarticks plants. According to authors, the allelochemicals may interfere in cell division in the formation of shank and xilematic vases, affecting therefore nutrients partition by the plantlet, resulting in changes in the aerial part growth, as well as of roots.

It is worth highlighting also that the effects of allelopathic compounds relate to receptor plant's physiological processes and, generally, act as growth inhibitors. However, the majority of those inhibitors in some concentration are stimulants as well as when they are present in smaller concentrations [16]. This factor, most likely, has been responsible for PCA increase of hairy beggarticks plantlets submitted to white clover and arrowleaf clover maceration extracts, as well as red clover extract by infusion in low concentrations.

Reduction in plantlet size increases competition potential of another crop over weed, since it decreased interference by the latter, mainly during the initial development stage, allowing for crop to stand out and to present dominance over the weed [17].

The allelochemicals action mode is related to the physiological processes in the plant, but their effect are not fully clarified, while the main difficulty is connected to the fact that substances affect more than one function, presenting phytotoxicity in many cases that originates more from generalized cell breakage than the specific action of a mechanism [18].

By analyzing the infra-red spectra, gotten from different extracts (Figure 5), it is possible to observe that due absorption intensity, the alcoholic extract enabled greater concentration of compounds, except for white clover, in which the extract by infusion presented greater concentration of compounds that the alcoholic.

It is observed that, regarding functional groups, there is presence of alcohols and phenol functional group in all extracts, with characteristic absorption of two bands, while the $\mathrm{O}-\mathrm{H}$ broad band in the range of $3400-3300$ $\mathrm{cm}^{-1}$, and another $\mathrm{C}-\mathrm{O}$ band in the range of $1300-1000 \mathrm{~cm}^{-1}$, there is also the presence of aromatic ring with characteristic absorption in the range of $1600-1450 \mathrm{~cm}^{-1}$. Those functional groups lead us to confirm the 


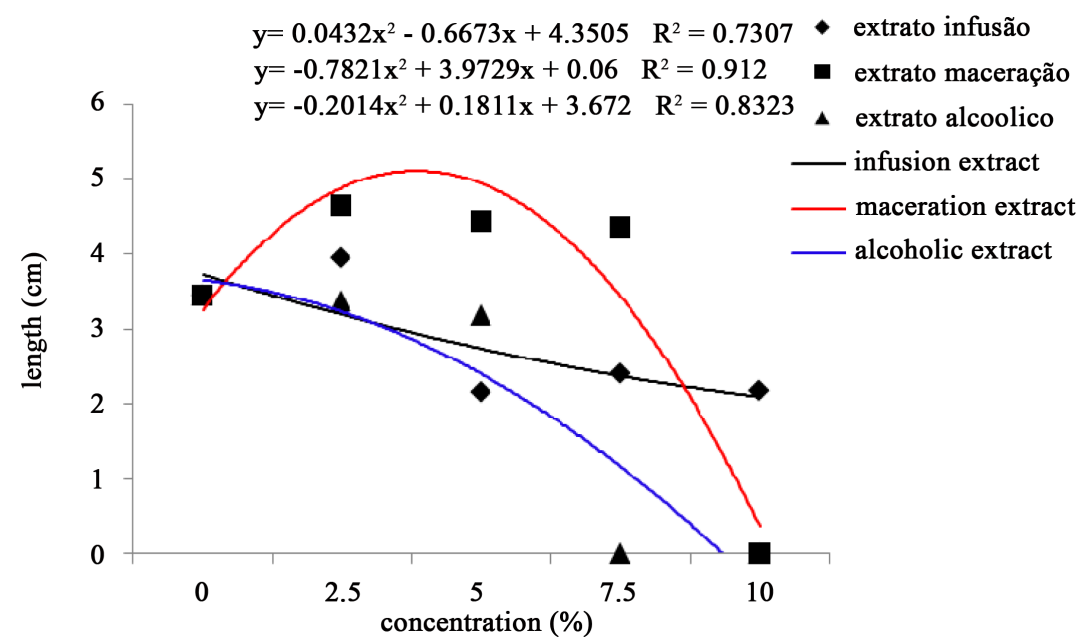

(a)

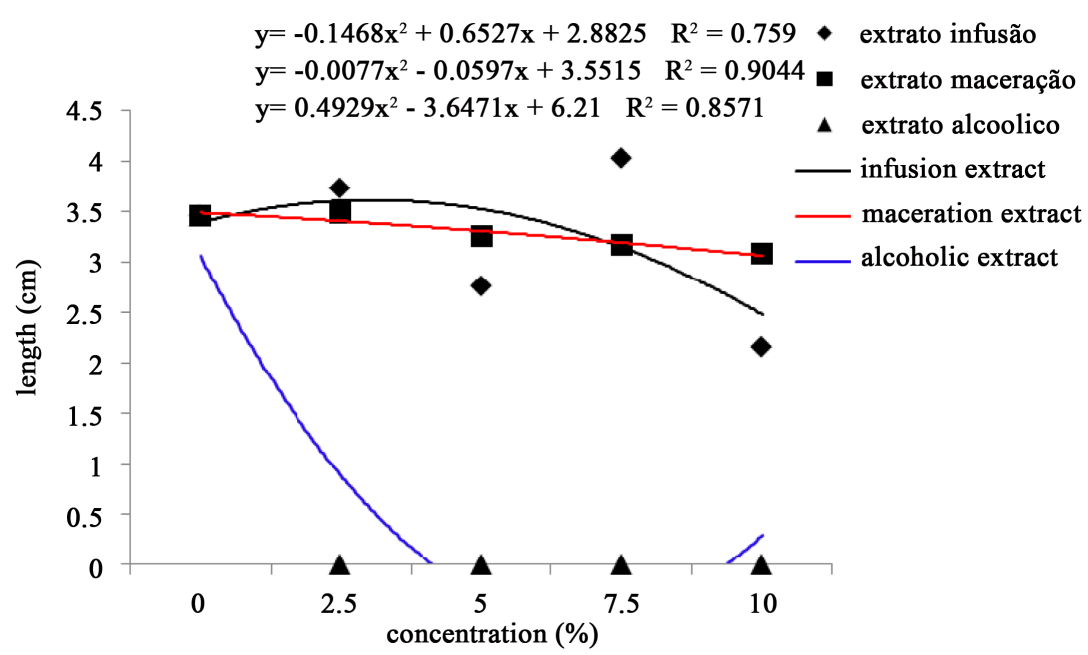

(b)

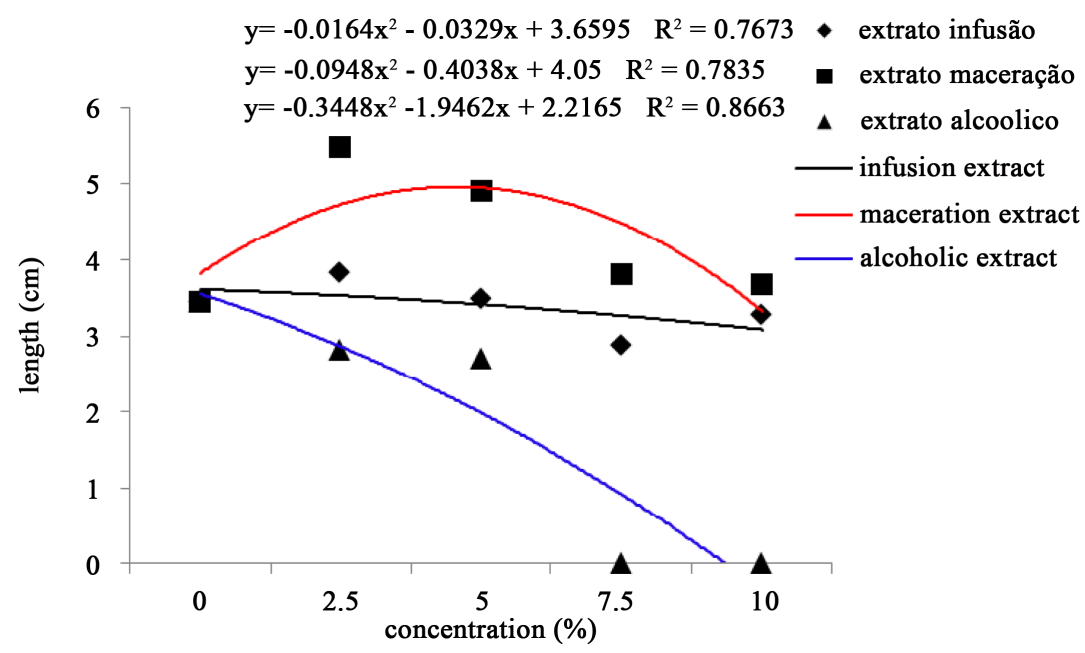

(c)

Figure 4. Aerial part length (cm) of hairy beggarticks's (Bidens sp.) plantlets submitted to application of different extracts from clover species ((a) — white clover, (b)—red clover, (c)—arrowleaf clover), UTFPR-Dois Vizinhos, 2014. 


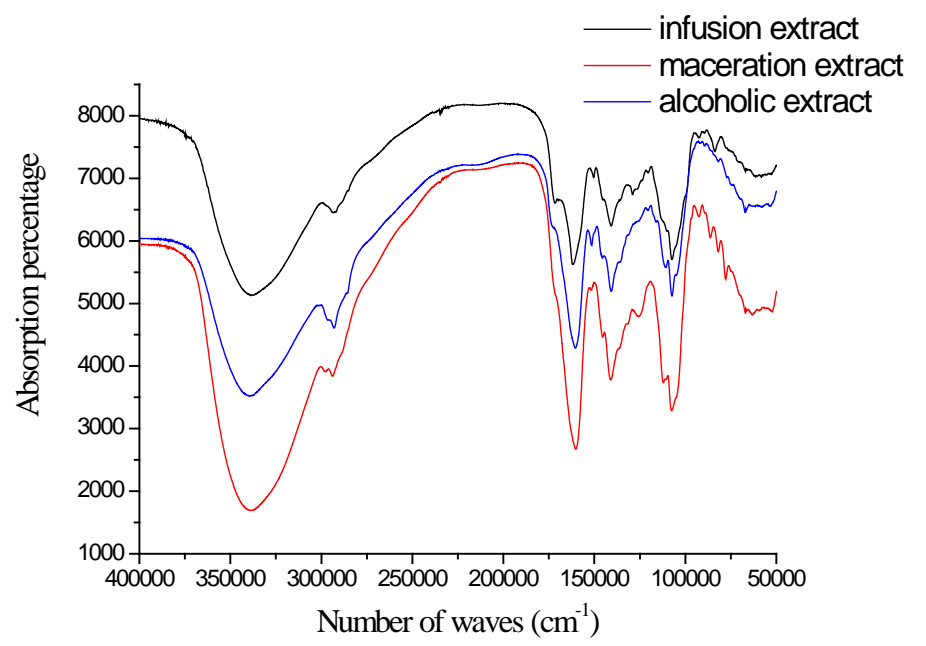

(a)

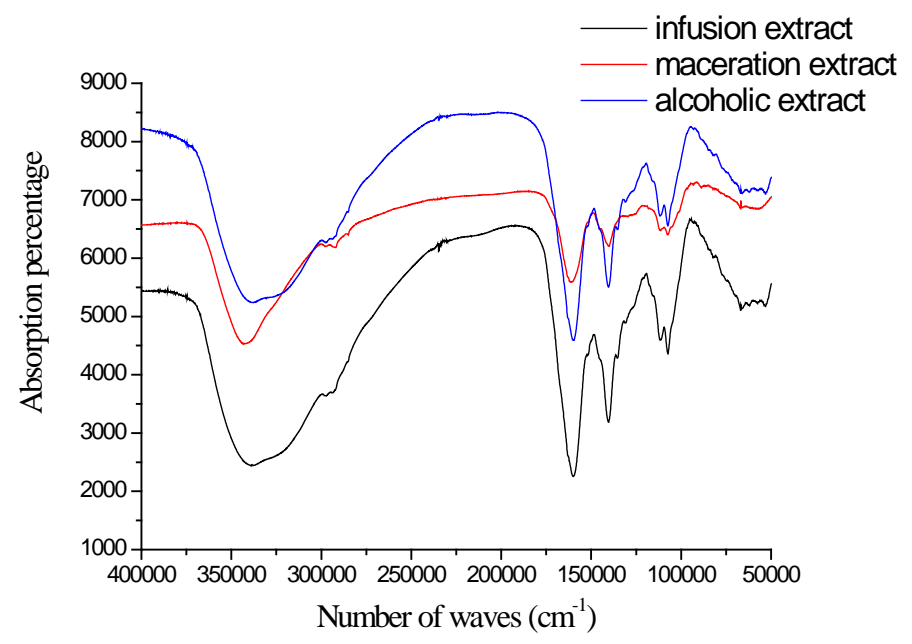

(b)

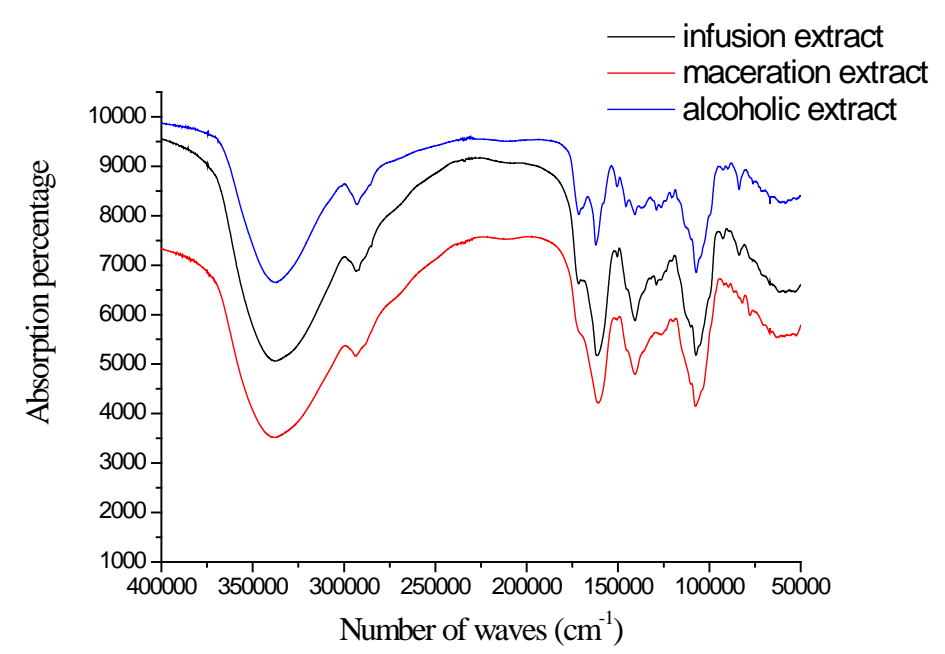

(c)

Figure 5. Infra-red spectrum of clover extracts ((a)—white clover; (b)—red clover; (c)—arrowleaf clover. UTFPR-Dois Vizinhos, 2014. 
Table 4. Aerial part length $(\mathrm{cm})$ of hairy beggarticks's (Bidens sp.) plantlets submitted to application of different extracts from clover species (A-white clover, B-red clover, C—arrowleaf clover). UTFP-Dois Vizinhos. 2014.

\begin{tabular}{ccccc}
\hline \multirow{2}{*}{ Type of extraction } & \multicolumn{3}{c}{ Clover species } \\
\cline { 2 - 5 } & White & Red & Arrowleaf & Mean \\
\hline Witness & $3.45 \pm 0.93^{\mathrm{aA}}$ & $3.45 \pm 0.93^{\mathrm{aA}}$ & $3.45 \pm 0.93^{\mathrm{aA}}$ & 3.45 \\
Infusion & $2.82 \pm 0.80^{\mathrm{aA}}$ & $3.22 \pm 0.82^{\mathrm{aA}}$ & $3.38 \pm 0.85^{\mathrm{bA}}$ & 3.14 \\
Maceration & $3.37 \pm 0.90^{\mathrm{aB}}$ & $3.28 \pm 0.89^{\mathrm{aB}}$ & $4.26 \pm 0.91^{\mathrm{aA}}$ & 3.64 \\
Alcoholic & $1.99 \pm 0.63^{\mathrm{bA}}$ & $0.69 \pm 0.66^{\mathrm{bB}}$ & $1.79 \pm 0.57^{\mathrm{cA}}$ & 1.49 \\
Mean & 2.91 & 2.66 & 3.22 & \\
\hline
\end{tabular}

Averages followed by the same lowercase letters in columns and by uppercase letter in the row do not differ in Tukey test ( $p$ $\leq 0.05)$

presence of phenolic compounds in all extracts of clover, since they are basically comprised by aromatic ring and hydroxyl grouping, while those are the main compounds of the allelopathic substances [7].

Concerning the extraction processes, it is likely to highlight that the alcoholic extract was more effective in extracting organic compounds from the dry material of clover, followed by the infusion and maceration extracts, respectively, except for the white clover species, in which extraction by infusion predominated over the other extraction processes.

It was found that, considering clover species, there was not spectrum difference maceration and infusion extracts obtained from the white clover and the arrowleaf clover, but the spectrum obtained from red clover was different compared to other clover species. In the other hand, spectra obtained from alcoholic extracts were different among all three clover species, showing that ethanol is more effective in extracting compounds than water. This is due because ethanol presents non-polar extremities, often considered as bipolar, while water is a polar substance [19]. That is, ethanol has the capability of extracting a greater number of substances from clover vegetal fibers than water, particularly phenolic compounds which, according to Taiz and Zeiger [7], comprise a chemically heterogeneous group, while some are soluble in organic solvents, others are not soluble in water, and others are practically insoluble.

It can be said that, regarding the infusion and maceration methods, the higher temperature used in infusion $\left(100^{\circ} \mathrm{C}\right)$ favored dilution of compounds in water, since, according to Watanabe [20], higher temperatures often favor the solubility of the solute in the solvent.

The allelopathic effect of white clover, red clover, and arrowleaf clover, is likely to be related to the isoflavonoids, which, according to Taiz and Zeiger [7], have several biological activities, standing out the antifungal and antibacterial activities (phytoalexins), estrogenic activity and pesticide properties, while those authors report the presence of isoflavonoids in clover plants.

The allelopathic effect of clover species in weed control should be deepened as in this initial work it was found that they presented effect on hairy beggarticks's germination and plantlets initial development, been a feasible alternative in weeds alternative control.

\section{Conclusions}

The white, red, arrowleaf clover species, in the different extraction ways, present allelopathic effect over hairy beggarticks's seeds and plantlets.

The main compound identified in spectra of clover extract was phenolic compound, and they were suggested as accountable for the allelopathic effect.

\section{References}

[1] Ferreira, M.C., de Souza, J.R.P. and de Jesus Faria, T. (2007) Allelopathy of Plant Extracts on Germination and Initial Growth of Beggartick (Bidens pilosa L.) and Lettuce (Lactuca sativa L.). Ciência Agrotecnica, 31, 1054-1060. http://www.scielo.br/pdf/cagro/v31n4/17.pdf

[2] Corsato, J.M., Fortes, A.M.T., Santorum, M. and Leszczynski, R. (2010) Allelopathic Effect of Sunflower Water 
Extract on the Germination of Soybean and Hairy Beggartick. Semina: Ciências Agrárias, 31, 353-360. http://dx.doi.org/10.5433/1679-0359.2010v31n2p353

[3] Nóbrega, L.H.P., de Lima, G.P., Martins, G.I. and Menhghetti, A.M. (2009) Soybean (Glycine max L. Merrill) Seed Germination and Plantlet Growth under Vegetation Cover. Acta Scientiarum, Agronomy, 31, 461-465. http://dx.doi.org/10.4025/actasciagron.v31i3.320

[4] Carvalho, A.M. (2006) As Rotate Crops: The Choice of Crops, It Should Be Compatible Grain Yield, Biomass and Soil Cover. Vol. 1, DBO Agrotecnologia, São Paulo, 30-31.

[5] Ferreira, G.A and Aquila, M.E.A. (2000) Alellopathy: An Emerging Topic in Ecophysiology. Revista Brasileira de Fisiologia Vegetal, 12, 175-204.

http://www2.esalq.usp.br/departamentos/lpv/lpv672/semana\%204/11\%20-\%20Referencia\%20para\%20leitura\%20-\%2 0\%20Alelopatia\%20na\%20agricultura.pdf

[6] Mazzafera, P. (2003) Allellopathic Effects of the Alcoholic Extract of Clove and Eugenol. Brazilian Journal of Botany, 26, 231-238. http://www.scielo.br/pdf/rbb/v26n2/a11v26n2.pdf

[7] Taiz, L. and Zeiger, E. (2013) Plant Physiology. Translate: Divan Junior et al., Artmed, Porto Alegre, 918.

[8] de Moraes, P.V.D., Agostinetto, D., Panozzo, L.E., Galon, L., Oliveira, C. and Dal Magro, T. (2012) Allelopathic Potential of Aqueous Extracts of Cover Crops on the Germination and Development of Bidens pilosa. Semina: Ciências Agrárias, 33, 1299-1314. http://dx.doi.org/10.5433/1679-0359.2012v33n4p1299

[9] Wardle, A.D., Ahmed, M. and Nicholson, K.S. (1991) Allelopathic Influence of Nodding Thistle (Carduns nutans L.) Seed on Germination and Radicle Growth of Pasture Plants. Journal Agriculture Research, 34, 185-191.

[10] da Silva Cruz, M.E., de Holanda Nozaki, M. and Batista, M.A. (2000) Medicinal Plants: Medicinal Plants and Allelopathy. Biotecnologia Ciência e Desenvolvimento, 15, 8-34. http://www.biotecnologia.com.br/revista/bio15/plantas.pdf

[11] Fortes, A.M.T., Mauli, M.M., Rosa, D.M., Piccolo, G., Marques, D.S. and de Carvalho Refosco, R.M. (2009) Allelophatic Effect of Sambucus australis Cham. and Schltdl. and Cymbopogon citratus (DC) Stapf. in the Germination of Bidens pilosa L. and Soybeans. Acta Scientiarum Agronomy, 31, 241-246.

[12] Ferreira, A.G. (2004) Interference: Competition and Allelopathy, In: Ferreira, A.G. and Borghetti, F., Eds., Germination from Basic to Applied, Artmed, Porto Alegre, 324.

[13] de Moura Pires, N., Souza, I.R.P., Prates, H.T., de Faria, T.C.L., Pereira Filho, I.A. and Magalhães, P.C. (2001) Effect of Leucaena Aqueous Extract on the Development, Mitotic Index and Peroxidase Activity in Maize Seedlings. Revista Brasileira Fisiologia Vegetal, 13, 55-65. http://www.scielo.br/pdf/rbfv/v13n1/9273.pdf

[14] Rickli, H.C., Fortes, A.M.T., Silva, P.S.S., Pilatti, D.M. and Hutt, D.R. (2011) Allelopathic Effect of Aqueous Extract of Azadirachta indica A. Juss. on Lettuce, Soybeans, Maize, Beans and Bidens pilosa. i: Ciências Agrárias, 32, $473-$ 484. http://dx.doi.org/10.5433/1679-0359.2011v32n2p473

[15] Gatti, A.B., Perez, S.C.J.G.A. and Lima, M.I.S. (2004) Allelopathic Activity of Aqueous Extracts of Aristolochia esperanzae O. Kuntze in the Germination and Growth of Lactuca sativa L. and Raphanus sativus L. Acta Botânica Brasílica, 18, 459-472. http://dx.doi.org/10.1590/S0102-33062004000300006

[16] Hoffmann, C.E.F., das Neves, L.A.S., Bastos, C.F. and da Luz Wallau, G. (2007) Allelopathic Activity of Nerium Oleander L. and Dief enbachia picta Schott in Seeds of Lactuca Sativa L. and Bidens pilosa L. Revista de Ciências Agroveterinárias, 6, 11-21.

[17] Goldfarb, M., Pimentel, L.W. and Pimentel, N.W. (2009) Allelopathy: Relations in Agro-Ecosystems. Tecnologia \& Ciência Agropecuaria, 3, 23-28.

[18] Einhellig, F.A. (1996) Interactions Involving Allelopathy in Cropping Systems. Agronomy Jornal, 88, 886-893. http://dx.doi.org/10.2134/agronj1996.00021962003600060007x

[19] Moreira, L.M., Rodrigues, M.R., de Oliveira, H.P.M., et al. (2010) Influence of Different Water-Ethanol Solvent Systems on the Spectroscopic and Physico-Chemical Properties of the Macrocyclic Compounds Pheophytin and Chlorophyll $\alpha$. Quimica Nova, 33, 258-262. http://dx.doi.org/10.1590/S0100-40422010000200005

[20] Watanabe, C.B., Nosse, T.M., Garcia, C.A. and Pinheiro, N.P. (2006) Extraction of the Essencial Oil from Menthol Mint (mentha arvensis) by Steam Distillation and Etanol Extraction. Revista Brasileira de Plantas Medicinais, 8, 76-86. http://www.sbpmed.org.br/download/issn_06_3/artigo15_v8_n4.pdf 


\section{Warmly welcome your paper submission to OALib Journal!}

- Publication on a daily basis

- 9 subject areas of science, technology and medicine

- Fair and rigorous peer-review system

- Fast publication process

- Article promotion in various social networking sites (LinkedIn, Facebook, Twitter, etc.)

- Widely-targeted and multidisciplinary audience to read your research

Submit Your Paper Online: Click Here to Submit

Contact Us: service@oalib.com 